УДК $33.021: 332.334 .4: 630^{*}: 633 / 635$ (477)

Опенько Іван,

кандидат економічних наук, доцент,

Національний університет біоресурсів і природокористування України, кафедра геодезії та картографії, м. Київ, ORCID ID: 0000-0003-2810-0778, e-mail: ivan_openko@ukr.net

https://doi.org/10.29038/2411-4014-2019-04-198-208

\title{
МАТЕМАТИЧНИЙ АНАЛІЗ ВПЛИВУ ЗЕМЕЛЬ ЛІСОГОСПОДАРСЬКОГО ПРИЗНАЧЕННЯ НА УРОЖАЙНІСТЬ СІЛЬСЬКОГОСПОДАРСЬКИХ КУЛЬТУР В УКРАЇНI: ЕКОНОМІЧНІ НАСЛІДКИ
}

В ході дослідження отримані результати розрахунків вказують на пряму кореляційну залежність між результативним показником (Y) - втратами деревного покриву в Україні визначених за даними Д33 Forest

Global Watch та детермінантами $\left(X_{1}-X_{5}\right)$ - урожайністю сільськогосподарських культур. Тобто при збільшенні втрат деревного покриву зростає урожайність, хоча наукові напрацювання вчених, щодо залежності урожайності с/г культур від лісистості території вказують протилежне. Причинами цього є збільшення норм внесення мінеральних добрив, через зміну мікрокліматичних умов вирощування сільськогосподарських культур внаслідок вирубок лісів, наукові обгрунтування таких тверджень наведені у відповідних наукових.

Ключові слова: математичний аналіз, землі лісогосподарського призначення, урожайність, коефіцієнт кореляції.

Опенько Иван,

кандидат экономических наук, доцент Национальный университет биоресурсов и природопользования Украины, кафедра геодезии и картографии,

г. Киев

\section{МАТЕМАТИЧЕСКИЙ АНАЛИЗ ВЛИЯНИЯ ЗЕМЕЛЬ ЛЕСНОГО ФОНДА НА УРОЖАЙНОСТЬ СЕЛЬСКОХОЗЯЙСТВЕННЫХ КУЛЬТУР В УКРАИНЕ: ЭКОНОМИЧЕСКИЕ ПОСЛЕДСТВИЯ}

В ходе исследования получены результаты расчетов указывают на прямую корреляционная зависимость между результативным показателем (Y) - потерями древесного покрова в Украине

определенных по данным Д33 Forest Global Watch и детерминантами $\left(X_{1}-X_{5}\right)$ - урожайностью сельскохозяйственных культур. То есть при увеличении потерь древесного покрова растет урожайность, хотя научные наработки ученых, о зависимости урожайности с/х культур от лесистости территории указывают обратное. Причинами этого является увеличение норм внесения минеральных удобрений, через изменение микроклиматических условий выращивания сельскохозяйственных культур в результате вырубок лесов, научные обоснования таких утверждений приведены в соответствующих научных.

Ключевые слова: математический анализ, земли лесного фонда, урожайность, коэффициент корреляции.

Openko Ivan,

PhD of Economic Sciences, Associate Professor, National University of Life and Environmental Sciences of Ukraine, Department of Geodesy and Cartography, 


\section{MATHEMATICAL ANALYSIS OF FOREST LAND EFFECT ON AGRICULTURAL CULTURES IN UKRAINE: ECONOMIC CONSEQUENCES}

With the current trend of population growth, an increase in the areas of urban agglomerations and industrial centers, rapid development of transport and tourist infrastructure, the role of forests is increasing in physical, geographical, aesthetic, sanitary and social aspects. World forest reserves annually generate between 20 and 30 billion tonnes of organic biomass, while depositing 30 to 50 billion tonnes of carbon dioxide, while replenishing atmospheric air. In temperate latitudes, 1 ha of forest area during the growing season emits an average of $25 \mathrm{~kg}$ of oxygen annually, while 1 ha of tropical forest produces about 60 tonnes of oxygen per year. Thus, providing the necessary conditions for life on our planet, forests are of particular social and ecological general biosphere importance.

The goal of the article is to investigate the impact of forest lands on crop yields in Ukraine and to outline the economic consequences of such interaction.

Thus, according to the results of our study, the direct impact of forest lands on crop yields can be argued.

Taking into account the fact that forest lands are involved in shaping the conditions of cultivation of crops, that is why the destruction of forest plantations leads to deterioration of microclimatic conditions of agricultural production, farmers have to increase the rate of application of mineral fertilizers, solve the problem of optimization of water management. increasing the cost of growing crops. Based on the calculations, it was proved that crop yields increase with decreasing forest cover $(\mathrm{R}=0.58-0.61)$, the reason for this being an increase in fertilizer application volumes $(\mathrm{R}=0.72)$.

The proposed regression model of the dependence of the amount of mineral fertilizers in growing crops on the area of loss of wood cover - according to Forest Global Watch, will be useful for experts in the field of agricultural production. The application of this model will allow us to predict the likely additional costs of growing crops in the event of deforestation in the region.

Such additional costs affect the health of agricultural products. In fact, on the basis of mathematical analysis, we found that the loss of wood cover ultimately affects the increase in average prices of agricultural products $(\mathrm{R}=0,63-0,78)$, which is a negative economic factor for the population.

Key words: mathematical analysis, forest land, productivity, correlation coefficient.

Постановка проблеми. При сучасній тенденції зростання кількості населення, збільшення площ міських агломерацій та промислових центрів, бурхливого розвитку транспортної та туристичної інфраструктури, роль лісів безмежно підвищується у фізико-географічному, естетичному, санітарно-гігієнічному, соціальному аспекті. Світові запаси лісових площ щорічно генерують від 20 до 30 млрд. т органічної біомаси, депонуючи при цьому 30 - 50 млрд. т вуглекислого газу та поповнюючи при цьому запаси атмосферного повітря. В помірних широтах 1 га лісових площ під час вегетаційного періоду виділяє щорічно в середньому до 25 кг кисню, тоді як 1 га тропічного лісу виробляє в рік близько 60 т кисню. Таким чином, забезпечуючи необхідні умови для життєдіяльності на нашій планеті, ліси перш за все мають особливе соціальне та екологічне загальнобіосферне значення.

Вирішення будь-яких проблем щодо раціонального природокористування в тому числі земель лісогосподарського призначення потребує глибокого та всебічного вивчення. В той же час будь-які управлінські, організаційні рішення повинні грунтуватися на певних наукових прогнозах щодо наслідків проектного природокористування, розробках заходів які запобігають впливу негативних факторів на довкілля та удосконаленні підходів при господарському плануванні 3 урахуванням екологічного фактору. Також для охорони земель лісогосподарського призначення необхідна потужна матеріально-технічна база з урахуванням сучасних досягнень техніки, зокрема, GNSS технологій, які дозволяють здійснювати облік лісових масивів (площ) з досить високою точністю; широкомасштабне впровадження технологій безвідходного (маловідходного) виробництва; збільшення обсягів випуску синтетичних (штучних) замінників природним матеріалам [1].

Водночас знищення значних лісових масивів, які регулюють кліматичні умови та водний режим величезних басейнів, як зазначають Г. І. Воробйов, К. Д. Мухамедшин, Л. М. Девяткин [2, С. 6], порушує встановлений мільйонами років екологічний баланс, що в свою чергу призводить до повсякчасних руйнівних паводків, селей, водних ерозійних процесів, пилових бурь, посух або 
заболоченості місцевості залежно від специфіки природно-кліматичних умов та характеру деревної рослинності.

Саме тому головним завданням нашого дослідження є встановлення математичного зв' язку між втратами деревного покриву та урожайністю сільськогосподарських культур, в умовах продовольчої безпеки нашої країни.

Аналіз останніх досліджень і публікацій. Роль земель лісогосподарського призначення у формуванні збалансованого природокористування є визначною. Зокрема, С. А. Генсірук [3], у своїй науковій роботі окреслив загальні еколого-економічні функції лісових земель у збереженні довкілля (рис. 1). Вчений наголосив на ефективності лісових масивів у зниженні звукового тиску до 30 ДцБ, що позитивно впливає на життєдіяльність населення поблизу автомобільних доріг. Разом 3 тим зелені насадження приймають участі у фільтруванні атмосферного повітря від сажі та пилу у деяких промислових містах. За розрахунками вченого «на 1 га ялинового лісу на хвої осідає до 32 т пилу, соснового - до 36, букового - до 68 т» [3, С. 333].

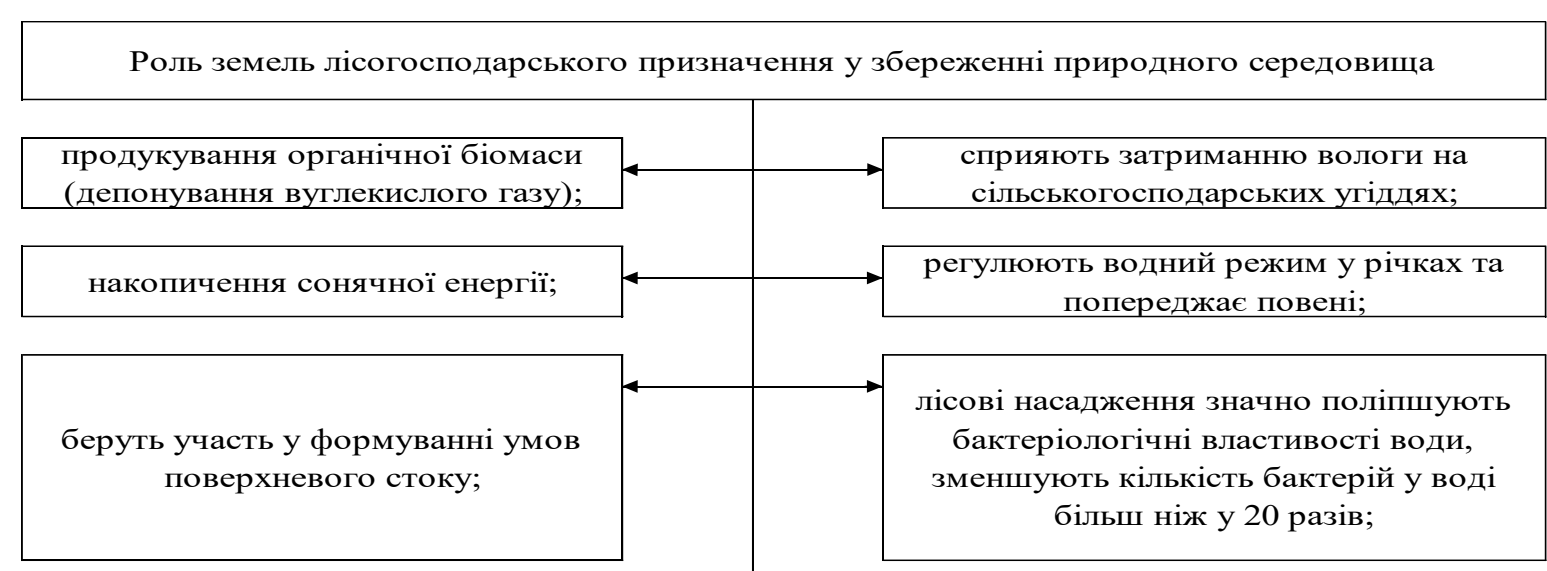

\begin{tabular}{|c|c|}
\hline $\begin{array}{c}\text { вироблення кисню (60 \% кисню на } \\
\text { планеті виробляє - ліс); }\end{array}$ & $\begin{array}{c}\text { багатотворний вплив на клімат, який } \\
\text { проявляється у зміні радіаційного та } \\
\text { температурного режимів. Лісові масиви } \\
\text { значно пом'якшують мікроклімат, } \\
\text { формують комфротну зону з ефективною } \\
\text { температурою } 17,2-21,7^{\circ} \mathrm{C} ;\end{array}$ \\
\hline
\end{tabular}

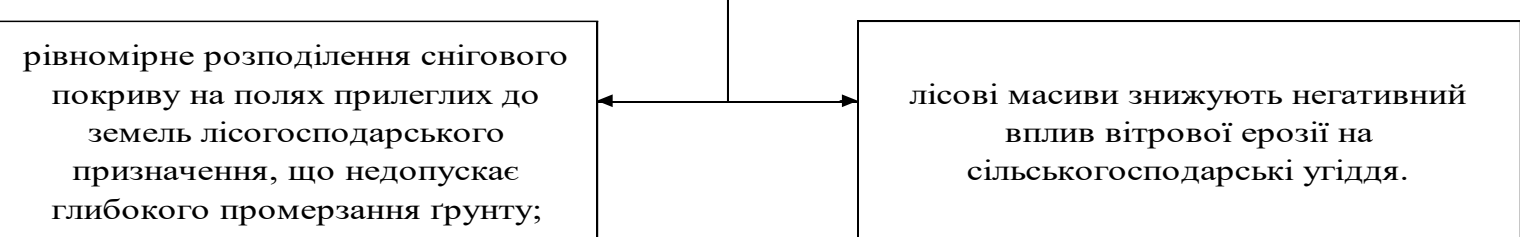

Рис. 1. Ефективність земель лісогосподарського призначення у формуванні системи збалансованого природокористування

Водночас землі лісогосподарського призначення $є$ невід'ємними компонентами біосфери, які безпосередньо впливають на геологічний, кліматичний, грунтотворний процес сталого розвитку довкілля [4]. Вчений А. А. Молчанов [5] у власних дослідженнях наводить науково-обгрунтовану схему кругообігу води, ключовим елементом якої $є$ лісові насадження (на даній схемі враховується випаровування вологи з крон дерев, вміст води в деревині тощо). Вплив лісу на збільшення кількості опадів в основному пов'язують з горизонтальним їх перехопленням і перерозподілом. В холодних і вологих поясах гір, де часті тумани і хмари «торкаються» поверхні землі, ліс конденсує у вигляді роси або мряки пароподібну вологу на гілках, листках, хвої, стовбурах. Таке явище називається горизонтальне перехоплення опадів [4, С. 21; 6 - 14]. 
Даний аспект є надзвичайно важливим, особливо якщо зважати на очікувані зміни клімату які призведуть до зміни температурних режимів, режимів випадання опадів і річкових стоків, від яких повністю залежить сільськогосподарське виробництво. Незважаючи на те, що для деяких умов сільськогосподарського виробництва, особливо у північних широтах, підвищення температури може стати перевагою, оскільки значно більша частина площі земель стане придатною для вирощування сільськогосподарських культур. Однак, райони розташовані у південних широтах, приймуть «основний удар» очікуваних негативних наслідків. За прогнозами, глобальне потепління сприятиме підвищенню частоти та інтенсивності посушливих періодів і повеней в субтропічних регіонах.

Дельти річок і прибережні райони будуть схильні до негативного впливу підвищення рівня моря. Гірські або високогірні системи і зрошувані системи, які залежать від танення снігу в літній період, також будуть залежати від зміни основних потоків у довгостроковій перспективі. У методах адаптації до зміни клімату та пом'якшення його наслідків основна увага повинна приділятися підвищенню стійкості сільськогосподарських агроландшафтів до таких ризиків, як посуха, надмірне випадання опадів і інші надзвичайні явища $[15$, С. 9].

Одним із головних факторів регулюванню наслідків глобального потепління $\epsilon$ позитивний вплив лісових насаджень у формуванні кліматичних умов на прилеглих сільськогосподарських угіддях. Найбільш ефективно ліси впливають на температурний, вітровий режими, опади та сонячний режим значних територій, як зазначає С. Г. Сініцин [16, С. 17 - 18]. Лісові насадження вирівнюють температурні коливання, значно знижуючи максимальні та мінімальні їх показники. Також, шляхом затінення кронами дерев прилеглі сільськогосподарських земель, температурний режим поверхні грунту знижується у період максимальної інсоляції в літній період часу. Завдяки такому «оберігаючому» впливу лісу на прилеглі угіддя, зменшується втрата тепла у нічний період, що у свою чергу запобігає (упереджуєт) появі заморозків. За дослідженнями вчених температура на поверхні грунту поблизу земель лісогосподарського призначення знижується у $2-2,5$ рази по відношенню до температурного режиму у відкритих полях.

Зважаючи на те що ліси впливають на формування сприятливого температурного режиму для сільськогосподарських культур, колектив науковців С. Е. Скотт, С. А. Монкс, Д. В. Спреклен, С. Р. Арнольд, П. М. Форстер, А. Рап та інші [17], у загальносвітовому масштабі, обгрунтували пряму залежність між збільшенням обсягів знищення лісових насаджень та зниженням урожайності сільськогосподарських культур.

Мета статті - на основі математичного аналізу, зокрема, кореляційного методу, дослідити вплив земель лісогосподарського призначення на урожайність сільськогосподарських культур в Україні та окреслити економічні наслідки від такої взаємодії.

Виклад основного матеріалу. За даними Державної служби статистики України нами були визначені показники урожайності сільськогосподарських культур за період 2001 - 2017 pp. [18] (табл. 1).

Таблиия 1

Динаміка урожайності сільськогосподарських культур в Украйні*

\begin{tabular}{|c|c|c|c|c|c|}
\hline \multirow{2}{*}{ Рік } & \multicolumn{4}{|c|}{ Урожайність сільськогосподарських культур, ц з 1 га зібраної площі } \\
\cline { 2 - 6 } & $\begin{array}{c}\text { Культури зернові та } \\
\text { зернобобові }\left(\mathrm{X}_{1}\right)\end{array}$ & $\begin{array}{c}\text { Буряк цукровий } \\
\text { фабричний }\left(\mathrm{X}_{2}\right)\end{array}$ & $\begin{array}{c}\text { Соняшник } \\
\left(\mathrm{X}_{3}\right)\end{array}$ & $\begin{array}{c}\text { Картопля } \\
\left(\mathrm{X}_{4}\right)\end{array}$ & $\begin{array}{c}\text { Культури } \\
\text { овочеві }\left(\mathrm{X}_{5}\right)\end{array}$ \\
\hline 2001 & 27,3 & 189,0 & 12,0 & 104,0 & 124,0 \\
\hline 2002 & 18,2 & 201,0 & 11,2 & 116,0 & 139,0 \\
\hline 2003 & 28,3 & 238,0 & 8,9 & 133,0 & 149,0 \\
\hline 2004 & 26,0 & 248,0 & 12,8 & 128,0 & 157,0 \\
\hline 2005 & 24,1 & 285,0 & 13,6 & 133,0 & 171,0 \\
\hline 2006 & 21,8 & 294,0 & 12,2 & 131,0 & 152,0 \\
\hline 2007 & 34,6 & 356,0 & 15,3 & 139,0 & 174,0 \\
\hline 2008 & 29,8 & 315,0 & 15,2 & 139,0 & 183,0 \\
\hline 2009 & 26,9 & 279,0 & 15,0 & 132,0 & 174,0 \\
\hline 2010 & 37,0 & 363,0 & 18,4 & 168,0 & 195,0 \\
\hline
\end{tabular}




\begin{tabular}{|l|l|l|l|l|c|}
\multicolumn{9}{c}{ Продовження таблиці 1 } \\
\hline 2011 & 31,2 & 411,0 & 16,5 & 161,0 & 199,0 \\
\hline 2012 & 39,9 & 399,0 & 21,7 & 160,0 & 200,0 \\
\hline 2013 & 43,7 & 477,0 & 19,4 & 176,0 & 208,0 \\
\hline 2014 & 41,1 & 436,0 & 21,6 & 161,0 & 206,0 \\
\hline 2015 & 46,1 & 482,0 & 22,4 & 166,0 & 211,0 \\
\hline 2016 & 42,5 & 475,0 & 20,2 & 168,0 & 208,0 \\
\hline 2017 & 47,4 & 509,0 & 23,0 & 171,0 & 214,0 \\
\hline
\end{tabular}

*Примітка: за даними Державної служби статистики України [18].

За допомогою кореляційного методу економіко-математичного аналізу нами були співставленні дані динаміки урожайності сільськогосподарських культур із втратами деревного покриву в Україні визначених за даними ДЗ3 Forest Global Watch (Y - результативний показник) (табл. 2).

В таблиці 2 зазначені розраховані нами коефіцієнти кореляції між результативним показником (втратою деревного покриву) та факторами які залежать від нього (урожайність сільськогосподарських культур).

Таблиия 2

\section{Результати кореляційного аналізу між урожайністю та зниженням деревного покриву за} даними ДЗ3 Forest Global Watch в Україні*

\begin{tabular}{|c|c|c|c|c|c|c|}
\hline & \multirow[b]{2}{*}{$\begin{array}{c}\text { Втрат деревного } \\
\text { покриву в Україні - } \\
\text { Forest Global Watch } \\
\text { (Y) }\end{array}$} & \multicolumn{5}{|c|}{ Урожайність сільськогосподарських культур } \\
\hline & & $\begin{array}{l}\text { Культури зернові } \\
\text { та зернобобові }\left(\mathrm{X}_{1}\right)\end{array}$ & $\begin{array}{c}\text { Буряк } \\
\text { цукровий } \\
\text { фабричний } \\
\left(\mathrm{X}_{2}\right)\end{array}$ & $\begin{array}{c}\text { Соняшн } \\
\text { ик }\left(\mathrm{X}_{3}\right)\end{array}$ & $\begin{array}{c}\text { Картопля } \\
\left(\mathrm{X}_{4}\right)\end{array}$ & $\begin{array}{c}\text { Культури } \\
\text { овочеві } \\
\left(\mathrm{X}_{5}\right)\end{array}$ \\
\hline Y & & $\mathbf{0 , 5 8}$ & 0,64 & 0,56 & $\mathbf{0 , 5 7}$ & $\mathbf{0 , 6 1}$ \\
\hline $\mathrm{X}_{1}$ & & & 0,91 & 0,91 & 0,87 & 0,86 \\
\hline $\mathrm{X}_{2}$ & & & & 0,92 & 0,94 & 0,95 \\
\hline $\mathrm{X}_{3}$ & & & & & 0,86 & 0,92 \\
\hline $\mathrm{X}_{4}$ & & & & & & 0,96 \\
\hline
\end{tabular}

Отримані результати розрахунків вказують на пряму кореляційну залежність між результативним показником $(\mathrm{Y})$ та детермінантами $\left(\mathrm{X}_{1}-\mathrm{X}_{5}\right)$ - урожайністю сільськогосподарських культур. Тобто при збільшенні втрат деревного покриву зростає урожайність, хоча наукові напрацювання вчених, щодо залежності урожайності с/г культур від лісистості території вказують протилежне [20].

Причинами цього $є$ збільшення норм внесення мінеральних добрив, через зміну мікрокліматичних умов вирощування сільськогосподарських культур внаслідок вирубок лісів, наукові обгрунтування таких тверджень наведені у відповідних наукових працях [21, 23 - 27].

Зокрема, завдяки зміні водного, температурного і повітряного режимів на прилеглих до лісових насадженнях сільськогосподарських угіддях, ефективність внесення добрив завжди вища ніж на відкритих ділянках [21].

Зважаючи на відомості Мамченкова І. П. [21, С. 13], а саме те що при внесенні мінеральних добрив поліпшуються умови росту рослин, однак, дози їх внесення повинні відповідати родючості грунту і запасів грунтової вологи. Нерідко при надмірному зростанні під впливом високих температур і нестачі вологи в грунті різко знижується урожай і олійність насіння.

Вплив мінеральних добрив на урожайність сільськогосподарських культур залежить від вологості грунту і тепла - нестача вологи у кореневмісному шарі спричиняє збільшення концентрації грунтового розчину, в результаті чого мінеральні добрива стають малоефективними або навіть негативно впливають на урожайність, за твердженням Милосердова М. М. [21]. 
Отже, при зниженні швидкості вітру, рівномірному розподілу снігу на полях і значному скороченню стоку талих вод на захищених лісовими насадженнями землях під час вегетаційного періоду формується особливий мікроклімат, який впливає на грунтові мікроорганізми, що переробляють мінеральні добрива у придатну для засвоєння рослинами форму [26]. Тому внесення мінеральних добрив у грунт на полях, захищених лісовими насадженнями, значно підвищує урожай сільськогосподарських культур, на відміну від внесення добрив на відкритих територіях, що підтверджують результати досліджень О. В. Альбенського [23], М. М. Милосердова [21], В. І. Коптєва [24], А. А. Лишенка [24], В. О. Каргова [25], С. С. Павловський [27, С. 78] та інші.

Натомість нами були здійснені відповідні математичні розрахунки, які підтверджують фактичну залежність збільшення норм внесення мінеральних добрив при зростанні площі втрат деревного покриву в Україні визначених за даними Д33 Forest Global Watch $(\mathrm{R}=0,72)$ (таблиця 3).

Таблиия 3

Розрахунок залежності між зниженням деревного покриву та обсягами внесення мінеральних добрив в Україні*

\begin{tabular}{|c|c|c|}
\hline Рік & $\begin{array}{c}\text { Втрата деревного } \\
\text { покриву в Україні за } \\
\text { даними Д33 - Forest } \\
\text { Global Watch, тис. га }\end{array}$ & $\begin{array}{c}\text { Загальний обсяг внесених } \\
\text { мінеральних добрив по Україні, } \\
1000 \text { т N, } \mathrm{P}_{2} \mathrm{O}_{5} \text { i } \mathrm{K}_{2} \mathrm{O}\end{array}$ \\
\hline 1 & 2 & 3 \\
\hline 2017 & 87,7 & 2028,1 \\
\hline 2016 & 110,0 & 1728,9 \\
\hline 2015 & 49,8 & 1415,0 \\
\hline 2014 & 47,9 & 1471,7 \\
\hline 2013 & 38,4 & 1493,8 \\
\hline 2012 & 56,2 & 1346,6 \\
\hline 2011 & 60,8 & 1266,9 \\
\hline 2010 & 52,7 & 1064,2 \\
\hline 2009 & 48,8 & 889,6 \\
\hline 2008 & 55,0 & 1068,5 \\
\hline 2007 & 64,9 & 899,8 \\
\hline 2006 & 42,7 & 702,0 \\
\hline 2005 & 37,0 & 560,5 \\
\hline 2004 & 50,1 & 521,2 \\
\hline 2003 & 39,4 & 381,6 \\
\hline 2002 & 27,6 & 401,7 \\
\hline 2001 & 29,2 & 403,9 \\
\hline \multicolumn{3}{|c|}{ Розрахунок коефіціснта кореляцї (R) } \\
\hline & $\begin{array}{c}\text { Втрата деревного } \\
\text { покриву в Україні за } \\
\text { даними Д33 - Forest } \\
\text { Global Watch, тис. га }\end{array}$ & $\begin{array}{c}\text { Загальний обсяг внесених } \\
\text { мінеральних добрив по Україні, } \\
1000 \text { т N, } \mathrm{P}_{2} \mathrm{O}_{5} \text { i K } \mathrm{K}_{2} \mathrm{O}\end{array}$ \\
\hline $\begin{array}{c}\text { Втрата деревного покриву в } \\
\text { Україні за даними ДЗ3 - Forest } \\
\text { Global Watch, тис. га }\end{array}$ & 1,00 & \\
\hline $\begin{array}{c}\text { Загальний обсяг внесених } \\
\text { мінеральних добрив по } \\
\text { україні, } 1000 \text { т N, } \mathrm{P}_{2} \mathrm{O}_{5} \text { i } \mathrm{K}_{2} \mathrm{O}\end{array}$ & $\mathbf{0 , 7 2}$ & 1,00 \\
\hline
\end{tabular}

*Примітка: розраховано автором за даними $[18,19,28]$. 
Зважаючи на те що втрата деревного покриву впливає на збільшення обсягу внесення мінеральних добрив нами була розроблене відповідне рівняння регресії, коефіцієнт детермінації якого становить 0,52 (формула 1):

$$
Y=105,89+17,64 \times X
$$

де $Y$ - обсяг внесення мінеральних добрив для вирощування сільськогосподарських культур;

$X$ - площа втрат деревного покриву визначений за даними ДЗ3 Forest Global Watch.

Такі обставини безпосередньо впливають на зростання середніх цін реалізації продукції сільського господарства сільськогосподарськими підприємствами, для споживачів про що свідчать дані розрахунків представлені в таблицях 4 та 5.

Таблиия 4

Матриця даних зниженням деревного покриву в Україні за даними Д33 Forest Global Watch та середні ціни реалізації продукції сільського господарства (2001 - 2017 рp.)*

\begin{tabular}{|c|c|c|c|c|c|c|c|c|c|}
\hline \multirow[b]{2}{*}{ 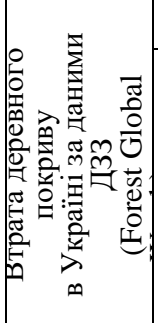 } & \multicolumn{9}{|c|}{ Середні ціни реалізованої продукції сільського господарства сільськогосподарськими підприємствами, грн/т } \\
\hline & 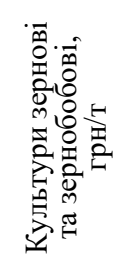 & 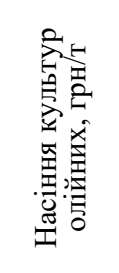 & 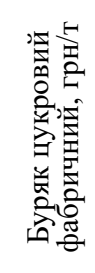 & 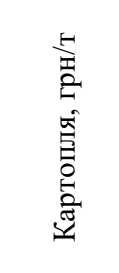 & 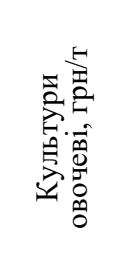 & 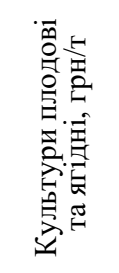 & 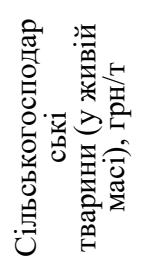 & 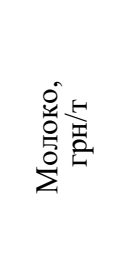 & 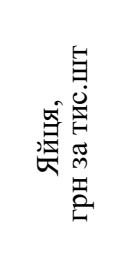 \\
\hline Y & $\mathrm{X}_{1}$ & $\mathrm{X}_{2}$ & $\mathrm{X}_{3}$ & $\mathrm{X}_{4}$ & $\mathrm{X}_{5}$ & $\mathrm{X}_{6}$ & $\mathrm{X}_{7}$ & $\mathrm{X}_{\mathrm{8}}$ & $\mathrm{X}_{9}$ \\
\hline 29,2 & 381,3 & 779,6 & 139,1 & 449,8 & 748,9 & 575,8 & 4175,5 & 603,7 & 210,0 \\
\hline 27,6 & 312,5 & 850,3 & 128,1 & 555,8 & 864,8 & 509,6 & 3644,0 & 541,0 & 168,1 \\
\hline 39,4 & 535,1 & 873,7 & 140,3 & 623,3 & 1012,7 & 434,0 & 3480,7 & 696,9 & 193,2 \\
\hline 50,1 & 453,1 & 1153,4 & 135,7 & 530,4 & 1225,0 & 740,1 & 5092,7 & 835,3 & 238,3 \\
\hline 37,0 & 417,8 & 981,5 & 177,0 & 685,2 & 1462,1 & 987,8 & 6909,9 & 1126,9 & 251,8 \\
\hline 42,7 & 515,2 & 1007,5 & 186,0 & 1070,3 & 1547,4 & 1446,1 & 6307,7 & 1070,2 & 192,7 \\
\hline 64,9 & 833,5 & 1866,8 & 157,6 & 1032,0 & 1995,4 & 1528,4 & 6466,5 & 1660,6 & 274,4 \\
\hline 55,0 & 778,6 & 1734,6 & 218,9 & 1154,3 & 2059,9 & 1877,4 & 10184,3 & 2065,1 & 377,4 \\
\hline 48,8 & 799,0 & 2086,2 & 409,9 & 1298,6 & 1790,0 & 1892,4 & 10362,9 & 1888,8 & 403,9 \\
\hline 52,7 & 1120,9 & 2942,6 & 478,5 & 2131,0 & 2551,6 & 2419,8 & 10797,1 & 2938,7 & 470,6 \\
\hline 60,8 & 1374,2 & 3312,0 & 516,0 & 2032,8 & 2139,1 & 3175,9 & 11967,2 & 3041,6 & 521,5 \\
\hline 56,2 & 1547,1 & 3584,0 & 426,8 & 1139,6 & 1956,6 & 2707,1 & 13456,9 & 2662,2 & 627,0 \\
\hline 38,4 & 1299,8 & 3087,5 & 397,8 & 1860,9 & 2354,0 & 3010,8 & 12901,3 & 3364,0 & 656,7 \\
\hline 47,9 & 1801,4 & 4062,8 & 494,2 & 2173,6 & 2514,3 & 2429,1 & 15736,9 & 3588,4 & 782,4 \\
\hline 49,8 & 2912,1 & 7531,5 & 788,6 & 2436,3 & 3903,4 & 5894,5 & 21966,2 & 4347,3 & 1333,2 \\
\hline 110,0 & 3414,0 & 8656,1 & 848,6 & 2631,8 & 3924,2 & 5863,8 & 22468,0 & 5461,8 & 1108,7 \\
\hline 87,7 & 3771,6 & 9132,0 & 825,3 & 3296,3 & 4136,1 & 8766,6 & 31838,4 & 7234,0 & 1145,9 \\
\hline
\end{tabular}


Розрахунок математичної залежності між зниженням деревного покриву в Україні та середніми цінами реалізації продукції сільського господарства (коефіціснти кореляції)*

\begin{tabular}{|c|c|c|c|c|c|c|c|c|c|c|}
\hline & $\mathrm{Y}$ & $\mathrm{X}_{1}$ & $\mathrm{X}_{2}$ & $\mathrm{X}_{3}$ & $\mathrm{X}_{4}$ & $\mathrm{X}_{5}$ & $\mathrm{X}_{6}$ & $\mathrm{X}_{7}$ & $\mathrm{X}_{8}$ & $\mathrm{X}_{9}$ \\
\hline $\mathrm{Y}$ & & $\mathbf{0 , 7 8}$ & $\mathbf{0 , 7 8}$ & $\mathbf{0 , 7 2}$ & $\mathbf{0 , 6 9}$ & $\mathbf{0 , 7 6}$ & $\mathbf{0 , 7 4}$ & $\mathbf{0 , 7 4}$ & $\mathbf{0 , 7 6}$ & $\mathbf{0 , 6 3}$ \\
\hline $\mathrm{X}_{1}$ & & 1,00 & 0,95 & 0,91 & 0,95 & 0,97 & 0,97 & 0,97 & 0,96 \\
\hline $\mathrm{X}_{2}$ & & & 0,96 & 0,91 & 0,96 & 0,97 & 0,97 & 0,96 & 0,96 \\
\hline $\mathrm{X}_{3}$ & & & & 0,94 & 0,94 & 0,93 & 0,94 & 0,94 & 0,95 \\
\hline $\mathrm{X}_{4}$ & & & & & 0,94 & 0,92 & 0,93 & 0,96 & 0,89 \\
\hline $\mathrm{X}_{5}$ & & & & & & & 0,94 & 0,95 & 0,95 & 0,94 \\
\hline $\mathrm{X}_{6}$ & & & & & & & 0,98 & 0,97 & 0,92 \\
\hline $\mathrm{X}_{7}$ & & & & & & & & 0,99 & 0,94 \\
\hline $\mathrm{X}_{8}$ & & & & & & & & & & 0,92 \\
\hline
\end{tabular}

*Примітка: розраховано автором за даними $[19,26]$.

Фактично нами встановлено що втрата деревного покриву в Україні [28] впливає на зростання середніх цін реалізації продукції сільського господарства сільськогосподарськими підприємствами, коефіцієнти кореляції змінюються від 0,63 до 0,78 по відповідним сільськогосподарським культурам (рис. 2).

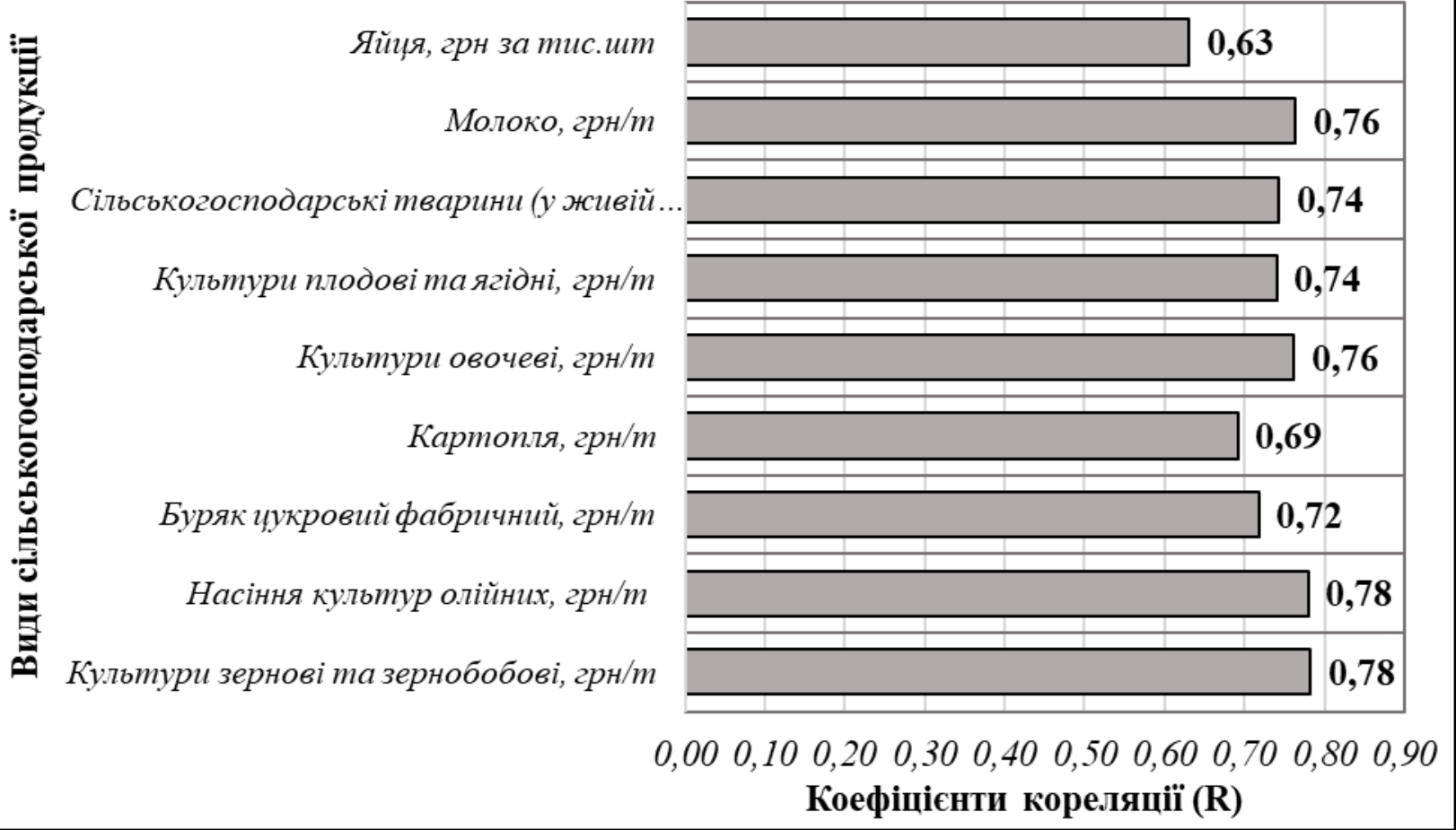

Рис. 2. Діаграма залежності иін реалізації сільськогосподарської продукиї із площею втрат деревного покриву в Україні

*Примітка: розраховано автором за даними $[19,26]$.

Висновки. Таким чином за результатами нашого дослідження можна стверджувати про безпосередній вплив земель лісогосподарського призначення на урожайність сільськогосподарських культур.

Враховуючи той факт що землі лісогосподарського призначення беруть участь у формуванні умов вирощування сільськогосподарських культур, саме тому знищення лісових насаджень 
призводить до погіршення мікрокліматичних умов сільськогосподарського виробництва, фермерам доводиться збільшувати норму внесення мінеральних добрив, вирішувати завдання оптимізації водного режиму грунту, що в кінцевому випадку впливає на збільшення затрат на вирощування сільськогосподарських культур. На основі розрахунків було доведено що урожайність сільськогосподарських культур підвищується при зниженні лісистості $(\mathrm{R}=0,58-0,61)$, причиною цьому є збільшення обсягів внесення мінеральних добрив $(\mathrm{R}=0,72)$.

Запропонована регресійна модель залежності обсягу внесення мінеральних добрив при вирощуванні сільськогосподарських культур від площі втрат деревного покриву - за даними ДЗ3 Forest Global Watch, буде корисною для фахівців в сфері сільськогосподарського виробництва. Застосування цієї моделі дозволить спрогнозувати ймовірні додаткові витрати, при вирощуванні сільськогосподарських культур у випадку зниження лісистості в регіоні.

Такі додаткові затрати впливають на здороження сільськогосподарської продукції. Фактично на основі математичного аналізу нами було встановлено що втрата деревного покриву в кінцевому випадку впливає на зростання середніх цін реалізації продукції сільського господарства $(\mathrm{R}=0,63$ $0,78)$, що є негативним економічним фактором для населення.

\section{Джерела та література}

1. Генсирук С. А. Рациональное природопользование: монография. Москва: Лесная промышленность, 1979. $312 \mathrm{c}$.

2. Воробьев Г. И., Мухамедшин К. Д., Девяткин Л. М. Лесное хозяйство мира: монография. Москва: Лесная промышленность, 1984. $352 \mathrm{c.}$

3. Генсірук С. А. Ліси України: монографія. Київ: Наукова думка, 1992. 408 с.

4. Ханбеков И. И., Недведцкий Н. А., Власюк В.Н. и др. Влияние леса на окружающую среду: монография. Москва: Лесная промышленность, 1980. 133 с.

5. Молчанов А. А. Влияние леса на окружающую среду: монография. Москва: Наука, 1973. 359 с.

6. Шевченко О. В., Опенько І. А. Теоретичні передумови раціонального сільськогосподарського землекористування. Збалансоване природокористування. 2017. № 3 С. $126-130$.

7. Шевченко О. В., Опенько І. А., Цвях О. М. Економічні передумови чергування культур як спосіб запобігання деградації агроландшафту. Землеустрій, кадастр і моніторинг земель. 2017. № 2. С. 58 - 65.

8. Tsvyakh O., Openko I. Main directions of urban land optimization in Kiev agglomeration. Baltic Surveying International Scientific Journal. 2017. Vol. 6_1. P. 60 - 65.

9. Цвях О. М., Опенько І. А. Промислові території, як просторовий базис оптимізації використання земель в місті Києві. Землеустрій, кадастр і моніторинг земель. 2017. № 1. С. 83 - 91.

10. Опенько І. А., Шевченко О. В., Цвях О. М. Аналіз наукових-методичних підходів до грошової оцінки земельних ділянок із полезахисними лісовими насадженнями. Збалансоване природокористування. 2016. № 4. C. $137-142$.

11. Опенько І. А., Свсюков Т. О. Удосконалення обліку кількості та якості земель під полезахисними лісовими насадженнями в кадастрово-реєстраційній системі. Збалансоване природокористування. 2014. № 3. C. $106-112$

12. Опенько І. А., Свсюков Т. О. Землі під полезахисними лісовими насадженнями: сучасний стан, проблеми, шляхи вирішення. Збалансоване природокористування. 2014. № 1. С.125 - 131.

13. Опенько I. А. Порівняльний аналіз оприлюднення земельно-кадастрових відомостей у зарубіжних країнах та Україні. Землеустрій, кадастр і моніторинг земель. 2013. № 3. С. 80 - 87.

14. Ievsiukov T., Openko I. An Inventory Database, Evaluation and Monitoring of Especially Valuable Lands at Regional Level in Ukraine. Elsivier, Procedia - Social and Behavioral Sciences, «GEOMED 2013» The 3rd International Geography Symposium June 10-13, 2013 Kemer, Antalya - Turkey. URL: http://www.sciencedirect.com/science/article/pii/S1877042814016619 (дата звернення: 07.10.2019).

15. ФАО 2012. Состояние мировых земельных и водных ресурсов для производства продовольствия и ведения сельского хозяйства. Управление системами, находящимися под угрозой. Продовольственная и сельскохозяйственная организация Объединенных Наций (Рим) и Издательство «Весь Мир» (Москва). 2012, 285 c. URL: http://www.fao.org/3/a-i1688r.pdf (дата звернення: 07.10.2019).

16. Синицын С. Г. и др. Лес и охрана природы: монография. Москва: Лесная промышленность, 1980. 288 c.

17. Scott C. E., Monks S. A., Spracklen D. V., Arnold S. R., Forster P. M., Rap A. and etc. Impact on short-lived climate forcers increases projected warming due to deforestation. Nature Communications, volume 9, Article number: 157 (2018). URL: https://www.nature.com/articles/s41467-017-02412-4 (дата звернення: 07.10.2019). 
18. Державна служба статистики У України. Рослинництво. URL: http://www.ukrstat.gov.ua/operativ/operativ2006/sg/sg_rik/sg_u/rosl_u.html (дата звернення: 07.10.2019).

19. Global Forest Watch. "Tree Cover Loss in [selected area name]". URL: www.globalforestwatch.org. (дата звернення: 07.10.2019).

20. Фещенко П. И. Лес и человек: монография. Киев: Урожай, 1970. 53 с.

21. Милосердов Н. М. Эффективность полезащитных лесных полос: монография. Киев: Урожай, 1971. 192 c.

22. Мамченков И.П. Справочник по удобрениям. Москва: Изд-во «Колос», $1964 . \quad$ URL: https://chem21.info/page/242076126089200134033035044082216099048253018157/ (дата звернення: 07.10.2019).

23. Альбенський А. В. Сельское хозяйство и защитное лесоразведение: монография. Москва: Колос, 1971. $279 \mathrm{c}$.

24. Коптєв В. І., Лишенко А. А. Лісові смуги - надійні захисники полів: монографія. Київ: Урожай, 1973. $92 \mathrm{c}$.

25. Каргов В. А. Опыт и эффективность защитного лесоразведения в степных и лесостепных районах: монография. Москва: науч. изд. ВНИИТЭИСХ, 1970. 46 с.

26. Державна служба статистики України. Середні ціни реалізованої продукції сільського господарства сільськогосподарськими підприємствами.

URL: http://www.ukrstat.gov.ua/operativ/operativ2006/sg/sg_rik/sg_u/scr_sp_u.html (дата звернення: 07.10.2019).

27. Павловский Е. С. Защитное лесоразведение в СССР: монография. Москва: Агропромиздат, 1986. 264 с.

28. Державна служба статистики України. Внесення мінеральних та органічних добрив (1990-2018). URL: http://www.ukrstat.gov.ua/operativ/operativ2018/sg/vmod/vmod1990-2017_u.zip (дата звернення: 07.10.2019).

\section{References}

1. Gensiruk, S. A. (1979), Ratsional'noye prirodopol'zovaniye [Rational nature management], Lesnaia promyshlennost', Moskow, Russian.

2. Vorob'ev, H. Y., Mukhamedshyn, K. D. and Devyatkyn L. M. (1984), Lesnoe khozyaystvo myra [Forestry of the world], Lesnaia promyshlennost', Moskow, Russian.

3. Gensiruk, S. A. (1992), Lisy Ukrayiny [Forests of Ukraine], Naukova dumka, Kyiv, Ukraine.

4. Khanbekov, I. I., Nedvedtskiy, N. A., Vlasyuk, V. N. et al. (1980), Vliyaniye lesa na okruzhayushchuyu sredu [Impact of the forest on the environment], Lesnaia promyshlennost', Moskow, Russian.

5. Molchanov, A. A. (1973), Vliyaniye lesa na okruzhayushchuyu sredu [Impact of the forest on the environment], Nauka, Moskow, Russian.

6. Shevchenko, O. V. and Openko, I. A. (2017), "Theoretical prerequisites for rational agricultural land use", Zbalansovane pryrodokorystuvannia, vol. 3, pp. 126-130.

7. Shevchenko, O. V. Openko, I. A. and Tsvyakh O. M. (2017), "Economic preconditions for alternating crops as a way to prevent degradation of the agro-landscape", Zemleustrij, kadastr i monitorynh zemel', vol. 2, pp. 58-65.

8. Tsvyakh, O. and Openko, I. (2017), "Main directions of urban land optimization in Kiev agglomeration", Baltic Surveying International Scientific Journal, vol. 6 (1), pp. 60-65.

9. Tsvyakh, O. M. and Openko, I. A. (2017), "Industrial territories as a spatial basis for optimizing the use of land in the city of Kiev", Zemleustrij, kadastr i monitorynh zemel', vol. 1, pp. 83-91.

10. Openko, I. A., Shevchenko, O. V. and Tsvyakh, O. M. (2016), "Analysis of scientific and methodical approaches to the monetary valuation of land with field-protective forest plantations", Zbalansovane pryrodokorystuvannia, vol. 4, pp. 137-142, available http://natureus.org.ua/index.php/ua/component/phocadownload/category/5-zbalansovane-prirodokoristuvannya-2016rik?download=17:zbalansovane-prirodokoristuvannya-4-2016 (Accessed 11 Jul 2019).

11. Openko, I. A. and Ievsiukov, T. O. (2014), "Improving accounting quantity and quality of land for shelter forest plantations in the cadastral registration system", Zbalansovane pryrodokorystuvannia, vol. 3, pp. 106-112

12. Openko, I. A. and Ievsiukov, T. O. (2014), "Lands under field-protective forest plantations: current state, problems, solutions", Zbalansovane pryrodokorystuvannia, vol. 1 . pp. 125-131, available at: http://www.natureus.org.ua/index.php/ua/component/phocadownload/category/3-zbalansovane-prirodokoristuvannya2014-rik?download=6:zbalansovane-prirodokoristuvannya-1-2014r (Accessed 11 Jul 2019).

13. Openko, I. A. (2013), "A comparative analysis of the publication of land cadastral data in foreign countries and Ukraine", Zemleustrij, kadastr i monitorynh zemel', vol. 3, pp. 80-87.

14. Ievsiukov, T. and Openko, I. (2013), "An Inventory Database, Evaluation and Monitoring of Especially Valuable Lands at Regional Level in Ukraine", Elsivier, Procedia - Social and Behavioral Sciences, "GEOMED 2013" The 3rd International Geography Symposium June 10-13, Kemer, Antalya, Turkey, available at: http://www.sciencedirect.com/science/article/pii/S1877042814016619. (Accessed 11 Jul 2019). 
15. FAO (2012), “The state of the world's land and water resources for food and agriculture. Managing systems at risk", available at: http://www.fao.org/3/a-i1688r.pdf

16. Sinitsyn, S. G. et al. (1980), Les i okhrana prirody [Forest and nature conservation], Lesnaia promyshlennost', Moskow, Russian.

17. Scott, C. E., Monks, S. A., Spracklen, D. V., Arnold, S. R., Forster, P. M., Rap, A. and etc. (2018), "Impact on short-lived climate forcers increases projected warming due to deforestation", Nature Communications, volume 9, article number - 157, available at: https://www.nature.com/articles/s41467-017-02412-4

18. State Statistics Service of Ukraine (2018), "Plant growing ", available at: http://www.ukrstat.gov.ua/operativ/operativ2006/sg/sg_rik/sg_u/rosl_u.html

19. Global Forest Watch (2018), "Tree Cover Loss in [selected area name]", available at: www.globalforestwatch.org (Accessed 23 August 2019).

20. Feshchenko, P. I. (1970), Les i chelovek [Forest and man], Urozhay, Kyiv, Ukraine.

21. Miloserdov, N. M. (1971), Effektivnost' polezashchitnykh lesnykh [Effectiveness of forest protection], Urozhay, Kyiv, Ukraine.

22. Mamchenkov, I. P. (1964), Spravochnik po udobreniyam [Fertilizer Reference], Kolos, Moskow, Russian, available at: https://chem21.info/page/242076126089200134033035044082216099048253018157/ (Accessed 23 August 2019).

23. Albensky, A. V. (1971), Sel'skoye khozyaystvo i zashchitnoye lesorazvedeniye [Agriculture and protective afforestation], Kolos, Moskow, Russian.

24. Koptev, V. I. and Lyshenko, A. A. (1973), Lisovi smuhy - nadiyni zakhysnyky poliv [Forest strips are reliable field defenders], Urozhay, Kyiv, Ukraine.

25. Karhov, V. A. (1970), Opyt i effektivnost' zashchitnogo lesorazvedeniya $v$ stepnykh i lesostepnykh rayonakh [Experience and effectiveness of protective afforestation in steppe and forest-steppe regions], VNIITEISKH, Moskow, Russian.

26. State Statistics Service of Ukraine (2018), “Average prices of agricultural products sold by agricultural enterprises”, available at: http://www.ukrstat.gov.ua/operativ/operativ2006/sg/sg_rik/sg_u/scr_sp_u.html (Accessed 28 August 2019).

27.Pavlovskiy, Ye. S. (1986), Zashchitnoye lesorazvedeniye v SSSR [Protective afforestation in the USSR], Agropromizdat, Moskow, Russian.

28. State Statistics Service of Ukraine (2018), “Application of mineral and organic fertilizers (1990-2018)", available at: http://www.ukrstat.gov.ua/operativ/operativ2018/sg/vmod/vmod1990-2017_u.zip (Accessed 28 August $\underline{2019) .}$ 